\title{
Rancang Bangun Kompor (Burner) Berbahan Bakar Oli Bekas
}

\author{
Annasruddin Pratama ${ }^{1}$, Basyirun ${ }^{1}$, Yohan Widhi Atmojo ${ }^{1}$, Gilang Wahyu Ramadhan ${ }^{1}$, Alif \\ Rivan Hidayat ${ }^{1}$ \\ ${ }^{1}$ Universitas Negeri Semarang \\ e-mail address : annas.pratama04@gmail.com
}

\begin{tabular}{|c|c|}
\hline Keywords: & Abstrak: \\
\hline $\begin{array}{l}\text { kompor; oli bekas; rancang } \\
\text { bangun; waktu konsumsi; } \\
\text { sifat nyala api }\end{array}$ & $\begin{array}{l}\text { Penelitian ini bertujuan untuk mengetahui rancang bangun kompor (burner) } \\
\text { berbahan bakar oli bekas, beserta spesifikasinya dan mengetahui hasil } \\
\text { pengujian menggunakan kompor (burner) pembakaran oli bekas. Berangkat } \\
\text { dari kurangnya pemanfaatan limbah oli bekas dan belum adanya alat yang } \\
\text { baik untuk memanfaatkan oli bekas tersebut. Disisi lain apabila digunakan } \\
\text { sebagai bahan bakar, oli bekas tidak menghasilkan pembakaran sempurna. } \\
\text { Penelitian ini menggunakan model perancangan French. Penelitian ini } \\
\text { disimpulkan bahwa kompor (burner) yang dirancang memiliki bentuk yang } \\
\text { besar dibandingkan pada burner pada umumnya. Kompor (burner) mencapai } \\
\text { tekanan } 3.5 \text { bar dengan suhu mencapai } 1127{ }^{\circ} \mathrm{C} \text {. Api yang dihasilkan oli } \\
\text { bekas berwarna jingga. Perbandingan bahan bakar menghasilkan data bahwa } \\
\text { elpiji lebih cepat } 16 \text { menit dibandingkan oli bekas dalam peleburan } \\
\text { alumunium. Panjang nyala api paling tinggi ialah } 1.57 \text { m pada variasi tekanan } \\
\text { udara } 3 \text { bar dan paling rendah ialah } 0.83 \text { m pada tekanan } 1 \text { bar. Adanya } \\
\text { pengaruh variasi tekanan terhadap temperatur pembakaran dengan temperatur } \\
\text { minimal dan maksimal mencapai titik tertinggi dengan tekanan sebesar } 2.5 \\
\text { bar dengan temperatur sebesar } 118{ }^{\circ} \mathrm{C} \text { dan } 994{ }^{\circ} \mathrm{C} \text { sedangkan untuk titik } \\
\text { terendah pada temperatur minimal dan maksimal pada tekanan } 1 \text { bar dengan } \\
\text { temperatur sebesar } 80,4 \text { }{ }^{\circ} \mathrm{C} \text { dan } 662{ }^{\circ} \mathrm{C} \text { dengan tekanan } 0,5 \text { bar. Waktu } \\
\text { konsumsi bahan bakar dengan variasi jarak sebesar } 2200 \text { km menghasilkan } \\
\text { waktu yang cukup singkat yaitu sebesar } 12 \text { menit } 25 \text { detik. Sedangkan waktu } \\
\text { konsumsi yang diperoleh dari variasi jarak } 1800 \text { km sebesar } 17 \text { menit } 11 \\
\text { detik. }\end{array}$ \\
\hline
\end{tabular}

\section{PENDAHULUAN}

Oli merupakan sisa dari produk-produk minyak bumi yang lain. Beberapa produk sisa adalah minyak bakar residu, minyak bakar untuk diesel, road oil, spray oil, coke, asphalt, dll [1]. Secara umum terdapat 2 macam oli bekas, yaitu oli bekas industri (light industrial oil) dan oli hitam (black oil). Oli bekas industri relatif lebih bersih dan mudah dibersihkan dengan perlakuan sederhana, seperti penyaringan dan pemanasan. Oli hitam berasal dari pelumasan otomotif [2]. Sejauh ini pemanfaatan oli bekas yang dilakukan oleh masyarakat masih belum maksimal terutama digunakan sebagai bahan bakar. Hal tersebut terjadi karena sedikitnya kompor (burner) yang berbahan bakar oli bekas langsung tanpa adanya campuran zat lain. Beberapa pengujian memerlukan zat tambahan agar oli bekas dapat dijadikan sebagai bahan bakar. Penambahan zat tersebut salah satunya menggunakan minyak propolis. Hasil dari percampuran tersebut berupa karakteristik nyala api yang dihasilkan berwarna kuning merah dengan ketinggian maksimal $25 \mathrm{~cm}$ [3]. Pada umumnya oli bekas dimanfaatkan masyarakat dengan berbagai cara seperti didaur ulang untuk digunakan lagi dengan cara oli bekas tersebut diberi tambahan zat kimia untuk memurnikannya. Namun hasil daur ulang tidak seperti oli yang masih baru. Selain itu digunakan sebagai penghilang karat pada knalpot, sebagai pengawet kayu dan pelumas rantai.

Mengutip dari majalah motor plus online, pemanfaatan limbah oli bekas untuk di daur ulang kembali berkisar $30 \%$ [4]. Imbas dari kurangnya pemanfaatan oli bekas yang belum maksimal mengakibatkan pencemaran lingkungan. Limbah oli tersebut bisa mengotori udara, tanah, dan air. Limbah minyak pelumas 
kemungkinan mengandung logam, larutan klorin, dan zat-zat pencemar lainnya. Satu liter limbah minyak pelumas dapat merusak jutaan liter air segar dari sumber air dalam tanah. Apabila limbah minyak pelumas tumpah di tanah akan mempengaruhi air tanah dan akan berbahaya bagi lingkungan. Hal ini karenan limbah minyak pelumas dapat menyebabkan tanah kehilangan unsur hara [5]. Selain itu limbah oli yang dibuang ke laut akan memengaruhi ekosistem laut yang dapat membunuh karang, ikan dan habitat lainnya di dalam laut.

Oli merupakan hasil dari penyulingan minyak bumi. Karakteristik oli juga tidak jauh dari minyak bumi yang digunakan sebagai bahan bakar. Maka bukan tidak mungkin oli bekas dapat digunakan sebagai bahan bakar. Namun, oli bekas tidak dapat mencapai pembakaran yang sempurna, seperti solar maupun bensin. Hal ini terjadi karena oli bekas tidak mudah terbakar sehingga tidak terjadi pengkabutan seperti bahan bakar pada umumnya. Walau demikian oli bekas dapat dimanfaatkan sebagai bahan bakar dengan mengoptimalkan pembakaran. Oli bekas memerlukan perlakuan khusus atau treatment agar dapat menjadi sebuah bahan bakar. Dalam perlakuan khusus tersebut ada dua pilihan yaitu dengan penambahan zat atau dengan cara pembakaran. Namun untuk menghasilkan kompor yang ekonomis, tentu diharapkan tanpa adanya penambahan zat melainkan dengan cara pembakaran oli bekas tersebut.

Rancangan kompor tersebut diharapkan memiliki nilai ekonomis yang lebih baik daripada menggunakan bahan bakar pada umumnya seperti bensin, elpiji, dan lain sebagainya. Pembakaran pelumas bekas dengan cara penguapan untuk menghasilkan emisi gas buang yang jauh lebih bersih. Sehingga asap yang dihasilkan tidak banyak dan tidak mengganggu daerah sekitar. Selain itu rancangan kompor tersebut harus memiliki kemudahan untuk pemeliharaannya (maintenance) [6]. Proses pemeliharaan yang mudah dapat meningkatkan nilai dari kompor tersebut. Berdasarkan beberapa model kompor yang telah dibuat belum memiliki tingkat pemeliharaan yang baik.

Berdasarkan permasalahan di atas maka peneliti tertarik untuk mengambil judul penelitian tentang "Rancang Bangun Kompor (Burner) Berbahan Bakar Oli Bekas".

\section{METODOLOGI PENELITIAN}

Metode penelitian menggunakan metode rancangan berbentuk deskriptif French, selain itu menggunakan pengujian water boiling test. Water boiling test disini tidak menggunakan media air namun lagsung diujicoba dengan meleburkan alumunium.

\section{Alat dan Bahan Penelitian}

Alat digunakan dalam penelitian ini adalah mesin las, kompresor, mesin bubut, tap, bor tangan, gerinda tangan, adapun bahan yang digunakan oli bekas, besi ST-44 untuk badan kompor, pipa besi, baut dan mur, spuyer berbahan kuningan, selang tembaga, pressure gauge, kran putar berbahan kuningan, selang plastik dan selang kompresor berbahan kuningan, termokopel tipe $\mathrm{K}$.

\section{Prosedur Penelitian}

Penelitian ini berupa rancang bangun, dengan menggunakan metode deskriptif French. Metode penelitian tersebut diawali memahami kebutuhan dari perancangan kompor berbahan bakar oli bekas, setelah itu menganalisis masalah dan pernyataan masalah. Langkah berikutnya merancangan konsep-konsep produk bertujuan untuk mendapatkan spesifikasi yang diinginkan. Memilih skets yang sesuai dengan efektifitas dan efisiennya alat tersebut. Langkah selanjutnya pemberian bentuk skets, detail dan gambar alat kerja, dan langkah terakhir adalah rancangan komponen secara keseluruhan. Selanjutnya dilakukan perbandingan melalui pengujian. Pengujian dalam penelitian ini menggunakan Water Boiling Test dan membandingkannya dengan bahan bakar elpiji dengan menggunakan kompor yang sama. Data yang telah didapatkan selanjutnya akan diolah dan dibuat menjadi sebuah laporan penelitian. 
Adapun diagram alir penelitian ini sebagai berikut:

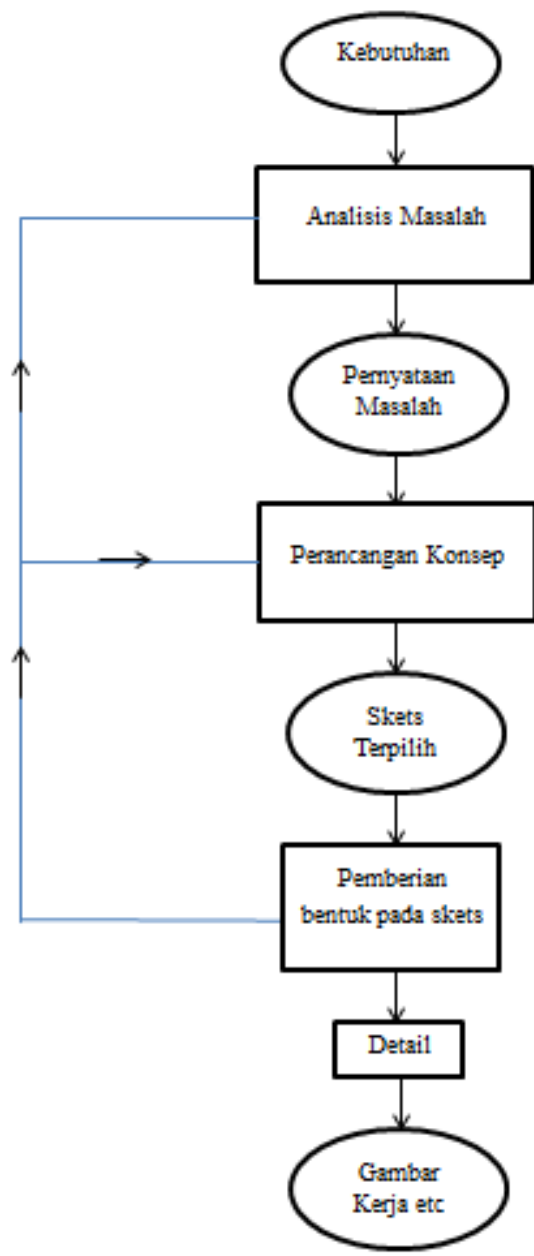

Gambar 1. Diagram alir penelitian French [7]

Penelitian diawali dengan mendesain kompor gas berbahan bakar oli bekas menggunakan software Autodesk Inventor 2015.

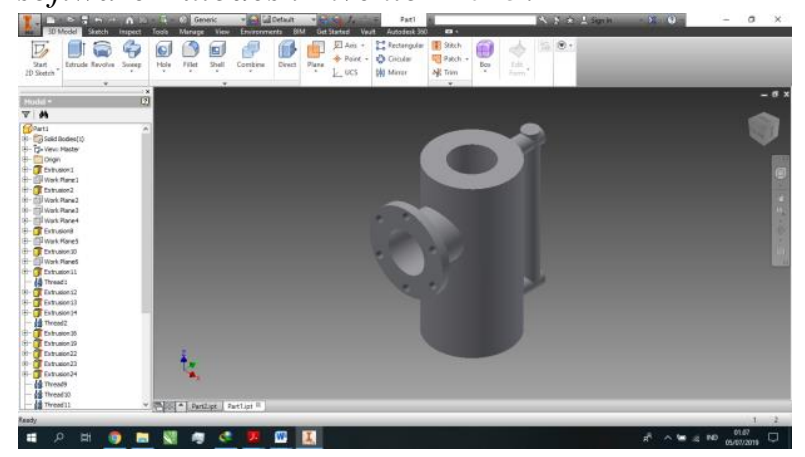

Gambar 2. Proses menggambar menggunakan

Autodesk Inventor 2015

Setelah itu menyiapkan alat dan bahan, kemudian melakukan proses pembuatan dengan menyatukan beberapa bagian dengan proses pengelasan, selain itu melakukan proses membubut pada bagian komponen bagian kompor sebagai tempat nozzle dan spuyer kompor, melakukan tap pada bagian penutup dan bawah kompor untuk nozzle dan spuyer. Setalah selesai rangkai komponen tersebut dan memasang bagian seperti pressure gauge, selang udara, selang oli, kran, dan termokopel. Uji coba produk dengan cara mengisi oli bekas ke badan kompor melalui selang oli. Setelah itu pasang lubang kompresor ke selang udara.

Berikut cara menghidupkan kompor (burner) tersebut. Lakukan start awal menggunakan solar dan di picu dengan pembakaran eksternal. Nyalakan aliran kompresor. Amati kompor tersebut. Setelah kompor gas yang telah dibuat sesuai dengan yang telah direncanakan. Maka langkah selanjutnya ialah pengumpulan data. Data yang dikumpulkan dimensi, kapasitas, nyala api, konsumsi bahan bakar, dan temperatur yang diperoleh. Selain itu dilakukan pengujian dengan water boiling test pada kompor oli berbahan bakar oli bekas gas elpiji.

\section{HASIL DAN PEMBAHASAN}

\section{Rancang Bangun Kompor (Burner) Berbahan Bakar Oli Bekas}

Kompor (burner) yang dirancang memiliki bentuk yang besar dibandingkan pada burner pada umumnya. Hal tersebut dikarenakan adanya penampungan oli di badan burner yang cukup luas sehingga oli tersebut dapat menghasilkan uap yang dapat digunakan sebagai bahan bakar. Bentuk kompor (burner) yang besar dan terbuat dari besi ST-44 yang lumayan tebal sehingga banyak memakan tempat ketika akan digunakan pada tungku peleburan, selain itu kompor ini tidak mudah untuk dipindahkan dari tempat satu ke tempat yang lain karena bebannya cukup berat. Untuk kran, selang udara, spuyer dan nozzle menggunakan bahan baku berupa kuningan. Untuk selang oli dan tangki oli menggunakan bahan berupa plastik. Pengoprasian kompor (burner) ini sedikit memakan waktu pada saat penyalaan api. Karena oli bukanlah bahan bakar seperti bensin atau gas elpiji yang mudah menyala. Pembakaran yang dihasilkan juga tidak termasuk dalam pembakaran sempurna. 
Kompor (burner) ini juga memiliki suara bising ketika digunakan. Kebisingan tersebut terjadi apabila kompor digunakan pada tekanan 3.5 bar. Meskipun demikian pada tekanan tersebut api memiliki suhu yang mencapai $1127{ }^{\circ} \mathrm{C}$. Penggunaan oli bekas sebagai bahan bakar merupakan langkah yang baik untuk mengurangi limbah tersebut. Sehingga limbah oli bekas tersebut tidak mencemari lingkungan baik tanah maupun udara.

\section{Spesifikasi Kompor (Burner) Berbahan Bakar Oli}

\section{Bekas}

Kompor (burner) berbahan bakar oli bekas tersebut terbuat dari baja ST-44 yang memiliki dimensi sebagai berikut badan kompor memiliki diameter $11,5 \mathrm{~cm}$. Sedangkan tinggi kompor gas $29 \mathrm{~cm}$. Bentuk badan kompor (burner) tersebut memiliki dimensi yang besar. Sehingga memiliki daya tampung yang besar pula. Karena didalam badan kompor tersebut dapat menampung 2,8 liter oli bekas. Meskipun besar kompor tersebut dapat menghasilkan api berwarna jingga dengan temperatur maksimal $1127{ }^{\circ} \mathrm{C}$. Kompor tersebut juga memiliki tekanan maksimal sebesar 3,5 bar. Namun tekanan tersebut menimbulkan suara yang bising dan api yang tidak stabil. Berikut tabel spesifikasi kompor (burner) berbahan bakar oli bekas.

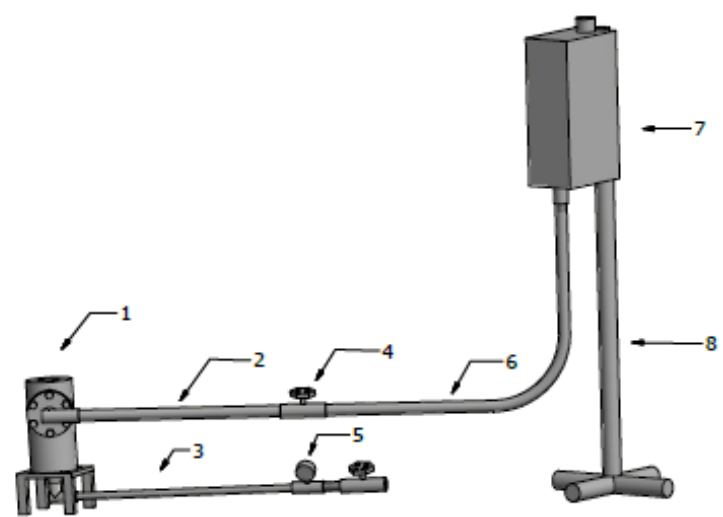

Gambar 3. Assembly Kompor (Burner) Berbahan Bakar Oli Bekas

Tabel 1. Keterangan Gambar 3

\begin{tabular}{|c|l|c|l|c|}
\hline No. & \multicolumn{1}{|c|}{ Nama } & Jumlah & \multicolumn{1}{|c|}{ Bahan } & Keterangan \\
\hline 1. & Badan Kompor & 1 & Baja ST-44 & \\
\hline 2. & Selang Aliran Oli & 1 & Pipa Besi & \\
\hline 3. & Selang Kompressor & 1 & Kuningan & \\
\hline 4. & Kran Putar & 2 & Kuningan & \\
\hline 5. & Pressure Gauge & 1 & & Mengukur dari $0-4$ Bar \\
\hline 6. & Selang Oli & 1 & Plastik & \\
\hline 7. & Tangki Oli & 1 & Plastik & \\
\hline 8. & Tiang Penyangga Tangki & 1 & Pipa Besi Galvanis & \\
\hline
\end{tabular}

Tabel 2. Spesifikasi Kompor

\begin{tabular}{|c|c|c|}
\hline No. & Spesifilkasi & Keterangan \\
\hline \multirow[t]{8}{*}{1.} & Bahan Pembuatan Kompor & \\
\hline & a. Badan Kompor & Baja ST-44 \\
\hline & b. Spuyer & Kumingan \\
\hline & c. Nozle & Kumingan \\
\hline & d. Selang Udara & Kumingan \\
\hline & e. Tangki Oli & Plastik \\
\hline & f. Selang Oli & Plastik \\
\hline & g. Kran Putar & Kumingan \\
\hline \multirow[t]{9}{*}{2.} & Dimensi Kompor & \\
\hline & a. Diameter Kounpor (cm) & $11,5 \mathrm{~cm}$ \\
\hline & b. Tinggi Kompor $(\mathrm{cm})$ & $29 \mathrm{~cm}$ \\
\hline & c. Diameter Spuyer (cm) & $2,5 \mathrm{~cm}$ \\
\hline & d. Tinggi Spuyer $(\mathrm{cm})$ & $2 \mathrm{~cm}$ \\
\hline & e. Diameter Noczie $(\mathrm{cm})$ & $2 \mathrm{~cm}$ \\
\hline & f. Tinggi Nozzle $(\mathrm{cm})$ & $4 \mathrm{~cm}$ \\
\hline & g. Panjang Selang Oli (cm) & $100 \mathrm{~cm}$ \\
\hline & h. Panjang Selang Udara $(\mathrm{cm})$ & $150 \mathrm{~cm}$ \\
\hline \multirow[t]{4}{*}{3.} & Bahan Bakar & \\
\hline & a. Jenis Bahan Bakar & Oli Bekas \\
\hline & b. Kapasitas Bahan Bakar (liter) & 2,8 Liter \\
\hline & c. Konsumsi Bahan Bakar (liter/jam) & 8 liter/ jam \\
\hline \multirow[t]{4}{*}{4.} & Nyala Api & \\
\hline & a. Nyala Api yang Dihasillkan & Jingga \\
\hline & b. Tekanan Maksimal & 3.5 bar \\
\hline & c. Temperatur Maksimal ("C) & $1127^{\circ} \mathrm{C}$ \\
\hline
\end{tabular}

Efisiensi yang Dihasilkan Oleh Kompor (Burner)

Berbahan Bakar Oli Bekas Dibandingkan dengan

\section{Kompor Berbahan Bakar Elpiji}

Kompor (burner) tersebut diuji dengan metode water boiling test dan membandingkan bahan bakar antara menggunakan oli bekas dengan elpiji. Air tersebut pada metode water boiling test diganti dengan alumunium sebesar $22 \mathrm{~kg}$. Peleburan alumunium menggunakan bahan bakar oli bekas tersebut memakan waktu 57 menit dengan menghabiskan 8 liter oli bekas. Sedangkan menggunakan bahan bakar gas elpiji memakan waktu sebesar 41 menit dengan menghabiskan waktu $2,1 \mathrm{~kg}$ gas elpiji. Temperatur pada tungku selama peleburan alumunium sebesar $22 \mathrm{~kg}$ tiap 10 menit menghasilkan grafik seperti berikut. Pengujian bahan bakar antara oli bekas dengan gas elpiji menggunakan kompor (burner) tersebut menggunakan tekanan yang sama yaitu 1.5 bar, menggunakan tekanan tersebut kompor (burner) dengan bahan bakar oli bekas mengeluarkan api yang relatif stabil begitu pula pada bahan bakar gas elpiji. Pengujian tersebut juga menghasilkan data bahwa elpiji lebih cepat 16 menit dibandingkan oli bekas. Hal ini dipengaruhi karena perbedaan nilai kalor antara gas elpiji dengan oli bekas. Gas elpiji memiliki nilai kalor 
yang lebih besar daripada oli bekas. Selain itu dalam pengoprasian, khususnya start awal. Pada start awal oli bekas lebih lama daripada gas elpiji. Hal ini disebabkan karena gas elpiji bahan bakar sehingga mudah terbakar dan tidak diperlukan perlakuan khusus. Temperatur api yang dihasilkan oli bekas memiliki perbedaan kurang lebih $200{ }^{\circ} \mathrm{C}$ dengan gas elpiji yang notabene adalah bahan bakar. Api yang dihasilkan oli bekas berwarna jingga sedangkan elpiji biru, hal ini disebabkan karena elpiji merupakan bahan bakar dengan pembakaran sempurna.

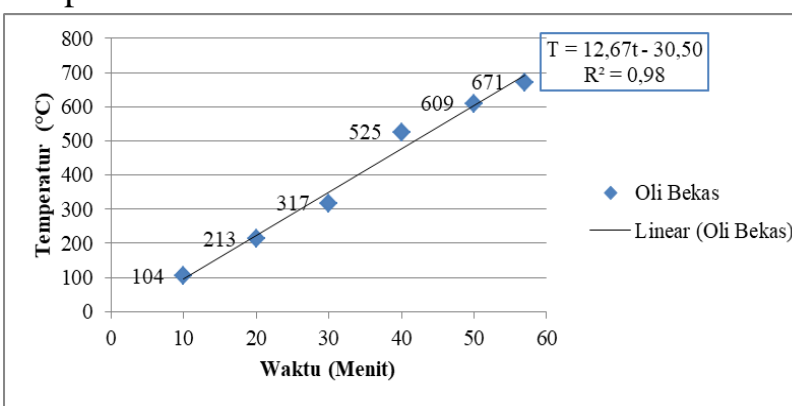

Gambar 4 Pengaruh temperatur tiap 10 menit pada tungku peleburan dengan bahan bakar oli bekas

Gambar 4 terdapat persamaan garis sebesar $\mathrm{T}=$ 12,67 (t) $+30,50$. Dalam persamaan tersebut diperoleh hubungan yang berbanding lurus, dimana persamaan garis $\mathrm{T}$ (temperatur) dipengaruhi oleh koefisien waktu (t). Koefisien tersebut sebesar 12,67 yang berarti adanya kenaikan temperatur sebesar 12,67 terhadap waktu yang ditambah dengan konstanta. Sedangkan konstanta tersebut sebesar $-30,50$, hal tersebut merupakan faktor luar, salah satunya yaitu suhu ruangan. Berdasarkan persamaan tersebut menghasilkan nilai R2 sebesar 0,98. R2 merupakan besarnya pengaruh waktu (t) terhadap Temperatur ( $\mathrm{T}$ ) yaitu sebesar $98 \%$. Nilai $2 \%$ merupakan faktor luar yang salah satunya yaitu suhu ruangan yang telah dibuktikan pada persamaan garis diatas. Persamaan tersebut hanya berlaku pada tekanan 10-57 Menit. Peningkatan suhu berkisar $100{ }^{\circ} \mathrm{C}$ - $200{ }^{\circ} \mathrm{C}$ tiap 10 menitnya. Peningkatan signifikan terjadi pada waktu 30 ke 40 menit, dengan suhu mulai dari $317{ }^{\circ} \mathrm{C}$ hingga ke 525 ${ }^{\circ} \mathrm{C}$. Kenaikan tersebut bekisar $208{ }^{\circ} \mathrm{C}$. Sedangkan untuk kenaikan terendah terjadi pada saat waktu 50 ke 57 menit, dengan suhu dari $609{ }^{\circ} \mathrm{C}$ hingga ke $671{ }^{\circ} \mathrm{C}$. Kenaikan tersebut berkisar $62{ }^{\circ} \mathrm{C}$. Melihat dari grafik tersebut, pada suhu yang ada pada tungku untuk meleburkan alumunium tidak stabil, hal ini disebabkan karena api yang disemburkan tidak stabil.

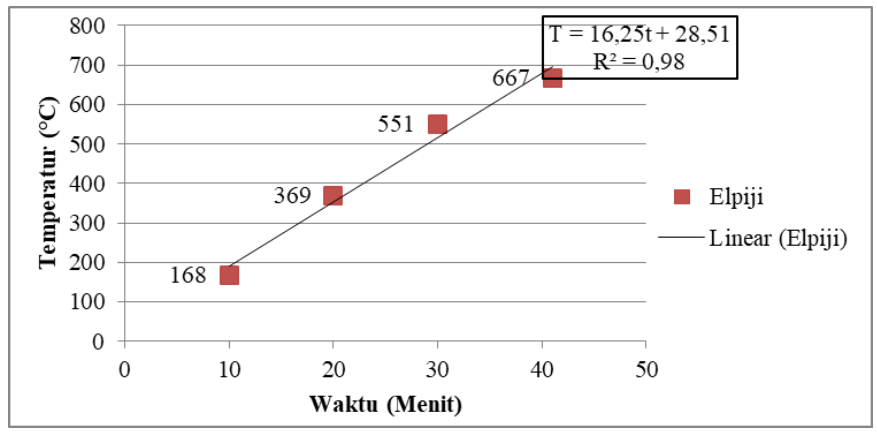

Gambar 5 Pengaruh temperatur tiap 10 menit pada tungku peleburan dengan bahan bakar elpiji

Gambar 5 terdapat persamaan garis sebesar $\mathrm{T}=$ 16,25 (t) $+28,51$. Dalam persamaan tersebut diperoleh hubungan yang berbanding lurus, dimana persamaan garis $\mathrm{T}$ (temperatur) dipengaruhi oleh koefisien waktu ( $\mathrm{t}$. Koefisien tersebut sebesar 16,25 yang berarti adanya kenaikan temperatur sebesar 16,25 terhadap waktu yang ditambah dengan konstanta. Sedangkan konstanta tersebut sebesar 28,51, hal tersebut merupakan faktor luar, salah satunya yaitu suhu ruangan. Berdasarkan persamaan tersebut menghasilkan nilai R2 sebesar 0,98. R2 merupakan besarnya pengaruh waktu (t) terhadap Temperatur (T) yaitu sebesar 98\%. Nilai $2 \%$ merupakan faktor luar yang salah satunya yaitu suhu ruangan yang telah dibuktikan pada persamaan garis diatas. Persamaan tersebut hanya berlaku pada tekanan 10-41 Menit. Peningkatan suhu berkisar $100{ }^{\circ} \mathrm{C}$ - $200{ }^{\circ} \mathrm{C}$ menitnya. Peningkatan signifikan terjadi pada waktu 10 ke 20 menit, dengan suhu mulai dari $168{ }^{\circ} \mathrm{C}$ hingga ke $369{ }^{\circ} \mathrm{C}$. Kenaikan tersebut bekisar $201{ }^{\circ} \mathrm{C}$. Sedangkan untuk kenaikan yang terendah terjadi pada saat waktu 30 ke 41 menit, dengan suhu dari $551^{\circ} \mathrm{C}$ hingga ke $667{ }^{\circ} \mathrm{C}$. Kenaikan tersebut bekisar $116{ }^{\circ} \mathrm{C}$. Melihat dari grafik tersebut, pada suhu yang ada pada tungku untuk meleburkan alumunium 
stabil, hal ini disebabkan karena api yang disemburkan stabil.

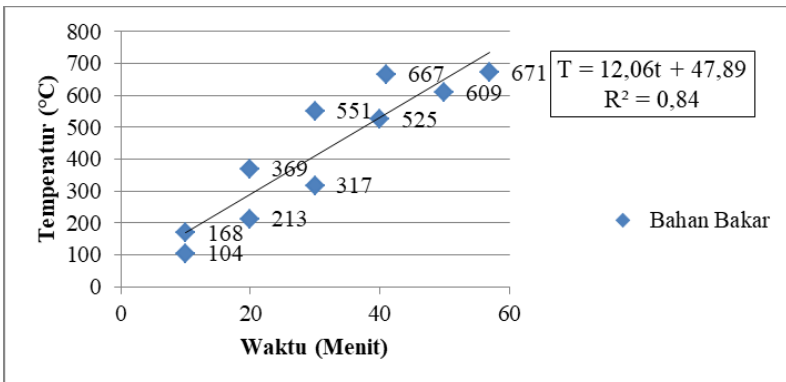

Gambar 6 Perbandingan pengaruh temperatur tiap 10 menit pada tungku peleburan antara bahan bakar oli bekas dan elpiji

Gambar 6 terdapat persamaan garis sebesar $\mathrm{T}=$ 12,06 (t) + 47,89. Dalam persamaan tersebut diperoleh hubungan yang berbanding lurus, dimana persamaan garis $\mathrm{T}$ (temperatur) dipengaruhi oleh koefisien waktu (t). Koefisien tersebut sebesar 12,06 yang berarti adanya kenaikan temperatur sebesar 12,06 terhadap waktu yang ditambah dengan konstanta. Sedangkan konstanta tersebut sebesar 47,89, hal tersebut merupakan faktor luar, salah satunya yaitu suhu ruangan. Berdasarkan persamaan tersebut menghasilkan nilai R2 sebesar 0,84. R2 merupakan besarnya pengaruh waktu (t) terhadap Temperatur (T) yaitu sebesar $84 \%$. Nilai $16 \%$ merupakan faktor luar yang salah satunya yaitu suhu ruangan yang telah dibuktikan pada persamaan garis diatas. Persamaan tersebut hanya berlaku pada tekanan 10-57 Menit. Berdasarkan nilai ekonomisnya oli bekas per liter memiliki nilai jual Rp. 2.500 dan elpiji seharga Rp. 10.250. Dengan demikian nilai ekonomis dari 8 liter oli bekas adalah 8 liter x Rp. $2.500=$ Rp. 20.000. Sedangkan untuk gas elpiji adalah $2.1 \mathrm{~kg}$. Sehingga $2.1 \mathrm{~kg}$ x Rp. $11.583=$ Rp. 24.324. Untuk nilai ekonomisnya dalam peleburan alumunium, oli bekas lebih murah daripada gas elpiji. Dari uraian diatas apabila dijadikan dalam bentuk tabel sebagai berikut.
Tabel 2. Perbandingan bahan bakar antara oli bekas dengan elpiji

\begin{tabular}{|c|l|l|}
\hline No. & \multicolumn{1}{|c|}{ Oli Bekas } & \multicolumn{1}{|c|}{ Elpiji } \\
\hline 1 & $\begin{array}{l}\text { Lebih Murah Harga } \\
\text { Bahan Bakarnya }\end{array}$ & $\begin{array}{l}\text { Lebih Mahal Harga } \\
\text { Bahan Bakarnya }\end{array}$ \\
\hline 2 & $\begin{array}{l}\text { Lebih Lambat Waktu } \\
\text { Peleburannya }\end{array}$ & $\begin{array}{l}\text { Lebih Cepat Waktu } \\
\text { Peleburannya }\end{array}$ \\
\hline 3 & Suhu Lebih Rendah & Suhu Lebih Tinggi \\
\hline 4 & $\begin{array}{l}\text { Pembakaran Tidak } \\
\text { Sempurna }\end{array}$ & $\begin{array}{l}\text { Pembakaran } \\
\text { Sempurna }\end{array}$ \\
\hline 5 & Start awal lambat & Start awal cepat \\
\hline
\end{tabular}

Hasil Pengujian Kompor (Burner) Tersebut

\section{Secara Umum yang Telah dilakukan}

\section{Pengaruh Tekanan Terhadap Sifat Nyala Api}

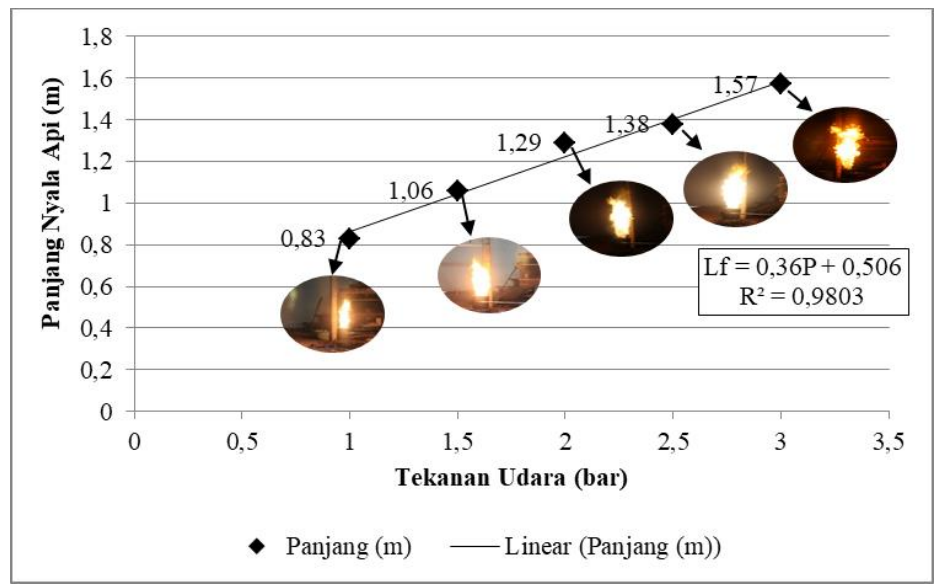

Gambar 7. Pengaruh tekanan terhadap panjang nyala api

Gambar 7 terdapat persamaan garis sebesar Lf = $0,36(\mathrm{P})+0,506$. Dalam persamaan tersebut diperoleh hubungan yang berbanding lurus, dimana persamaan garis Lf (Panjang Nyala Api) dipengaruhi oleh koefisien tekanan udara (P). Koefisien tersebut sebesar 0.36 yang berarti adanya kenaikan panjang nyala api sebesar 0.36 terhadap tekanan udara yang ditambah dengan konstanta. Sedangkan konstanta tersebut sebesar 0.506, hal tersebut merupakan faktor luar, salah satunya yaitu tekanan atmosfer. Berdasarkan persamaan tersebut menghasilkan nilai R2 sebesar 0,9803. R2 merupakan besarnya 
pengaruh Tekanan Udara (P) terhadap Panjang Nyala Api (Lf) yaitu sebesar 98,03\%. Nilai $1.97 \%$ merupakan faktor luar yang salah satunya yaitu tekanan atmosfer yang telah dibuktikan pada persamaan garis diatas. Persamaan tersebut hanya berlaku pada tekanan 1-3 Bar. Hasil pengujian menunjukkan bahwa semakin tinggi variasi tekanan udara maka nyala api yang dihasilkan akan semakin tinggi dan sebaliknya [8].

\section{Pengaruh Tekanan Udara Terhadap Temperatur}

\section{Pembakaran}

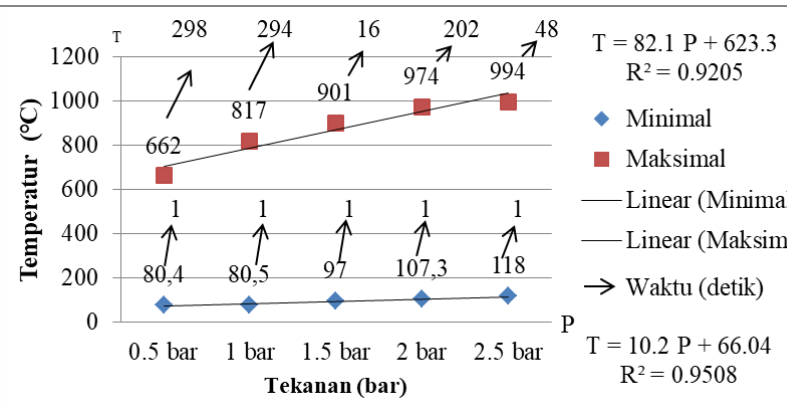

Gambar 8. Pengaruh tekanan terhadap temperatur pembakaran

Gambar 8 menghasilkan 2 persamaan garis yaitu $\mathrm{T}=82.1 \mathrm{P}+623.3$ untuk temperatur maksimal, dan $\mathrm{T}=10.2 \mathrm{P}+66.04$ untuk temperatur minimal. Dalam persamaan pada temperatur maksimal tersebut diperoleh hubungan yang berbanding lurus, dimana persamaan garis $\mathrm{T}$ (temperatur) dipengaruhi oleh koefisien tekanan udara $(\mathrm{P})$. Koefisien tersebut sebesar 82.1 yang berarti adanya peningkatan temperatur sebesar 82.1 terhadap tekanan udara yang ditambah dengan konstanta. Sedangkan konstanta tersebut sebesar 623.3 hal tersebut merupakan faktor luar, salah satunya yaitu tekanan atmosfer. Berdasarkan persamaan tersebut menghasilkan nilai R2 sebesar 0,9205. R2 merupakan besarnya pengaruh Tekanan Udara $(\mathrm{P})$ terhadap temperatur pembakaran $(\mathrm{T})$ yaitu sebesar $92,05 \%$. Nilai $7.95 \%$ merupakan faktor luar yang salah satunya yaitu tekanan atmosfer yang telah dibuktikan pada persamaan garis diatas. Persamaan tersebut hanya berlaku pada tekanan 0.5-2,5 Bar. Dalam persamaan pada temperatur minimal tersebut diperoleh hubungan yang berbanding lurus, dimana persamaan garis $\mathrm{T}$ (temperatur) dipengaruhi oleh koefisien tekanan udara (P). Koefisien tersebut sebesar 10.2 yang berarti adanya peningkatan temperatur sebesar 10.2 terhadap tekanan udara yang ditambah dengan konstanta. Sedangkan konstanta tersebut sebesar 66.04 hal tersebut merupakan faktor luar, salah satunya yaitu tekanan atmosfer. Berdasarkan persamaan tersebut menghasilkan nilai R2 sebesar 0,9508. R2 merupakan besarnya pengaruh Tekanan Udara (P) terhadap temperatur pembakaran (T) yaitu sebesar $95,08 \%$. Nilai $4.92 \%$ merupakan faktor luar yang salah satunya yaitu tekanan atmosfer yang telah dibuktikan pada persamaan garis diatas. Persamaan tersebut hanya berlaku pada tekanan 0.5-2,5 Bar. Hasil pengujian menunjukkan bahwa semakin tinggi variasi tekanan udara maka temperatur pembakaran semakin tinggi dan sebaliknya [9].

\section{Pengaruh Pengaruh jenis oli bekas terhadap}

\section{konsumsi waktu bahan bakar}

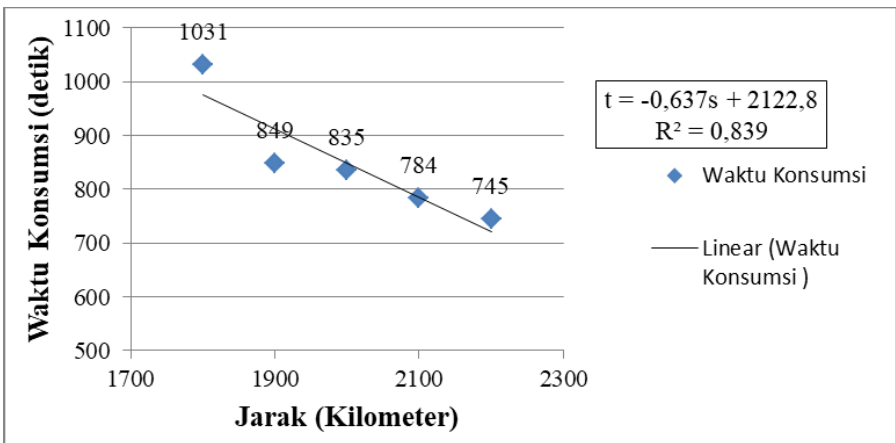

Gambar 9 Pengaruh jenis oli bekas terhadap konsumsi waktu bahan bakar

Dari gambar 9 didapatkan persamaan garis $\mathrm{t}=$ 0,637 (s) + 2122,8 Dalam persamaan tersebut terdapat hubungan yang berbanding terbalik, persamaan garis $\mathrm{t}$ (Waktu Konsumsi Bahan Bakar) dipengaruhi oleh koefisien jenis oli bekas. Koefisien $-0,637$ artinya terjadinya penurunan waktu konsumsi bahan bakar sebesar 0,637 terhadap jenis oli bekas ditambah dengan konstanta. Sedangkan konstanta 2122,8 merupakan faktor luar atau faktor penambah yang salah satunya yaitu kekentalan (viskositas) pada oli bekas. Persamaan tersebut hanya berlaku pada jarak 1800-2200 Km. Berdasarkan 
persamaan tersebut dapat dilihat bahwa $\mathrm{R}^{2}$ sebesar 0,839 . $\mathbf{R}^{2}$ merupakan sumbangan pengaruh jenis oli bekas (s) terhadap Waktu Konsumsi Bahan Bakar (t) yaitu sebesar 83,9\%. Nilai $17.1 \%$ merupakan faktor luar yang salah satunya yaitu kekentalan (viskositas) yang telah dibuktikan pada persamaan garis diatas. Pada jenis oli bekas dengan jarak $1800 \mathrm{~km}$ waktu konsumsi yang dibutuhkan untuk menghabiskan oli bekas 0,8 liter adalah 1031 detik yang merupakan waktu paling lama dari semua jenis oli bekas. Pada jenis oli bekas dengan jarak $2200 \mathrm{~km}$ diperlukan waktu 745 detik dan waktu tercepat untuk menghabiskan 0,8 liter oli bekas [10].

\section{KESIMPULAN}

1. Kompor (burner) yang dirancang memiliki bentuk yang besar dibandingkan pada burner pada umumnya. Penggunaan oli bekas sebagai bahan bakar merupakan langkah yang baik untuk mengurangi limbah tersebut. Pembakaran yang dihasilkan juga tidak termasuk dalam pembakaran sempurna.

2. Kompor (burner) ini memiliki spesifikasi sebagai berikut:

Badan kompor berbahan baja ST-44 dan pipa uap yang terbuat dari besi. Spuyer, nozzle, kran, serta selang kompressor terbuat dari kuningan. Tekanan maksimum yang digunakan ialah 3.5 bar, pada tekanan tersebut api memiliki suhu yang mencapai $1127{ }^{\circ} \mathrm{C}$. Api yang dihasilkan oli bekas berwarna jingga.

3. Pengujian tersebut juga menghasilkan data bahwa menggunakan elpiji lebih cepat 16 menit dibandingkan oli bekas. Hal ini dipengaruhi karena perbedaan nilai kalor antara gas elpiji dengan oli bekas. Temperatur api yang dihasilkan oli bekas memiliki perbedaan kurang lebih $100{ }^{\circ} \mathrm{C}$ dengan gas elpiji yang notabene adalah bahan bakar. Adanya pengaruh waktu terhadap kenaikan suhu yang terjadi pada tungku. Pengaruh tersebut terjadi ketika semakin lama tungku tersebut dipanaskan, akan semakin panas pula tungku tersebut.
Berdasarkan ekonomisnya oli bekas memiliki nilai Rp. 20.000. Sedangkan untuk gas elpiji Rp. 24.324. Untuk nilai ekonomisnya dalam peleburan alumunium, oli bekas lebih murah daripada gas elpiji.

4. Kesimpulan hasil penelitian secara umum yang telah dilakukan sebagi berikut:

a. Pengaruh tekanan terhadap sifat nyala api

Hasil pengujian menunjukkan bahwa semakin tinggi variasi tekanan udara maka nyala api yang dihasilkan akan semakin tinggi dan begitu pula sebaliknya. Nyala api yang paling stabil pada tekanan 3 bar dengan panjang lidah api $1.57 \mathrm{~m}$. Sementara nyala api pada tekanan 1 bar dengan panjang lidah api $0.83 \mathrm{~m}$.

b. Pengaruh tekanan terhadap waktu temperatur pembakaran

Hasil pengujian menunjukkan bahwa semakin tinggi variasi tekanan udara maka temperatur pembakaran juga semakain tinggi dan begitu pula sebaliknya. Temperatur minimal memiliki temperatur terendah yaitu $80,4{ }^{\circ} \mathrm{C}$ dengan tekanan 0.5 bar, sedangkan tertinggi ialah $118{ }^{\circ} \mathrm{C}$ dengan tekanan 2.5 bar. Untuk temperatur maksimal, temperatur terendah didapatkan pada tekanan 0.5 bar dan temperatur sebesar $662{ }^{\circ} \mathrm{C}$, sedangkan temperatur tertinggi dengan tekanan 2.5 bar dan temperatur yang dihasilkan sebesar $994{ }^{\circ} \mathrm{C}$. Adapun waktu yang didapat untuk mencapai temperatur maksimal, waktu yang tercepat ialah sebesar 16 detik, dengan tekanan sebesar 1.5 bar. Waktu terlama ialah 298 detik, dengan tekanan sebesar 0.5 bar.

c. Pengaruh variasi jenis oli bekas berdasarkan penggunaannya terhadap waktu konsumsi

Hasil pengujian menunjukkan bahwa pengaruh variasi jenis oli bekas didasarkan pada penggunaan berupa jarak tempuh yang diperoleh pada penggunaan oli bekas tersebut menghasilkan waktu konsumsi bahan bakar. Waktu konsumsi bahan bakar dengan variasi jarak terjauh akan lebih 
cepat habis dibandingkan dengan jarak yang tidak jauh. Dimana pada variasi jarak sebesar $2200 \mathrm{~km}$ menghasilkan waktu yang cukup singkat yaitu sebesar 12 menit 25 detik. Sedangkan waktu konsumsi yang diperoleh dari variasi jarak $1800 \mathrm{~km}$ sebesar 17 menit 11 detik.

\section{REFERENSI}

[1] A. Amri, H. Hamri, \& F. A. Sofyan, "Analisis Nilai Ekonomis Oli Bekas Pada Kompor Bertekanan Berpemanas Awal." J-Move: Jurnal Teknik Mesin, vol. 1, no. 1, 2019.

[2] W. P. Raharjo, "Pemanfaatan TEA (Three Ethyl Amin) Dalam Proses Penjernihan Oli Bekas Sebagai Bahan Bakar Pada Peleburan Aluminium." Jurnal Penelitian Sains \& Teknologi, vol. 8, no. 2, pp. 166 - 184, 2007.

[3] G. Rubiono, dan R. Mustika, "Sosialisasi Manajemen Limbah Oli Bengkel Mobil Pengabdian Masyarakat di Desa Pesucen Kecamatan Kalipuro Kabupaten Banyuwangi." vol. 1, Pp. 5-9, 2017.

[4] Asidu, L. A. Darsono, M. Hasbi, and P. Aksar. "PEMANFAATAN MINYAK OLI BEKAS SEBAGAI BAHAN BAKAR ALTERNATIF DENGAN PENCAMPURAN MINYAK PIROLISIS." ENTHALPY 2.2, 2017.

[5] Ridho, A. 2018. Serius, Oli Bekas Bisa Jadi Baru Layak Pakai Cuma dengan 2 Langkah? Begini Kata Ahlinya. https://www.motorplusonline.com/read/251260061/serius-oli-bekasbisa-jadi-baru-layak-pakai-cuma-dengan-2langkah-begini-kata-ahlinya. $28 \quad$ Juli 2020. (18.48).

[6] W. P. Raharjo, "Pemanfaatan Oli Bekas Sebagai Salah Satu Alternatif Solusi Untuk Mengurangi Kebutuhan Minyak Bakar.” Jurnal Mekanika, vol. 3, no. 1, pp. 23 -25, 2004.

[7] H. D.Harsokoesoemo, "Pengantar Perancangan Teknik." Bandung : ITB, 2004.

[8] Y. W. Atmojo, "Pengaruh Variasi Tekanan Udara Terhadap Waktu Konsumsi Bahan Bakar dan Sifat Nyala Api Pembakaran Oli Bekas Pada Kompor." Skripsi. Universitas Negeri Semarang, 2020.

[9] G. W. Ramadhan, "Pengaruh Tekanan Udara Terhadap Temperatur Pembakaran Oli Bekas Pada Kompor." Skripsi. Universitas Negeri Semarang, 2020.

[10] A. R. Hidayat, "Pengaruh Jenis Oli Bekas (Jarak Tempuh Perjalanan) Sebagai Bahan Bakar Kompor Pengecoran Logam Terhadap Waktu Konsumsi dan Suhu Maksimal Pada Pembakaran." Skripsi. Universitas Negeri Semarang, 2020. 